\title{
REMEMBERING ÜLO HUSSAR - ESTONIAN PROFESSOR OF HISTOLOGY AND EMBRYOLOGY
}

\author{
Piret Hussar \\ Department of Anatomy, Institute of Biomedicine and Translational Medicine, Tartu
}

On 13 June 2018, the Estonian histologist and embryologist, Professor Ülo Hussar M.D., D.M.Sc would have become 85 years old. Ülo Hussar was born as one of four children in a farmer's family in Vastseliina, Võru County, in 1933. In bombing during World War II, the farmhouse was destroyed by fire and Ülo Hussar continued his studies at Võru Secondary School, living in the school's dormitory. He graduated from Võru Secondary School with a prize in 1952 and from the Faculty of Medicine at the University of Tartu in 1959. As during his student days Ülo Hussar showed great interest in science, being mentored by Prof. Julius Tehver, he was sent in 1960 to continue his research as a postgraduate student at the Institute of Experimental Medicine in St. Petersburg, where in 1963 he defended his dissertation entitled "Repair of thymus after whole body and local radiation" ("Регенераторные процесы в тимусе при общем и местном рентгеновском облучений”). Having returned to Estonia, he entered the doctoral programme and graduated it with the defence of the dissertation "Quantitative experimental-clinical histology of the lymphoid tissue in norm and radiation" ("Количественный экспериментально-клинический анализ лимфойдной ткани в норме и при радиацонном поражений”) at Tartu State University in 1972.

Ülo Hussar's main research interest was studying the histomorphogenesis of lymphoid tissue. He was the first in the former USSR to describe the biorhythms of thymolymphocytes' mitochondrial division (1963). While studying the regeneration of thymus during radiation, he discovered radiosensitivity of microtymolymphocytes (1967) and was among the first in the world to describe the recovery of the thymolymphoid tissue after radioactive radiation (previously it was assumed that there is no post-radioactive ability for the recovery of tissues). He composed an original scheme of lymphocytes' proliferation and 


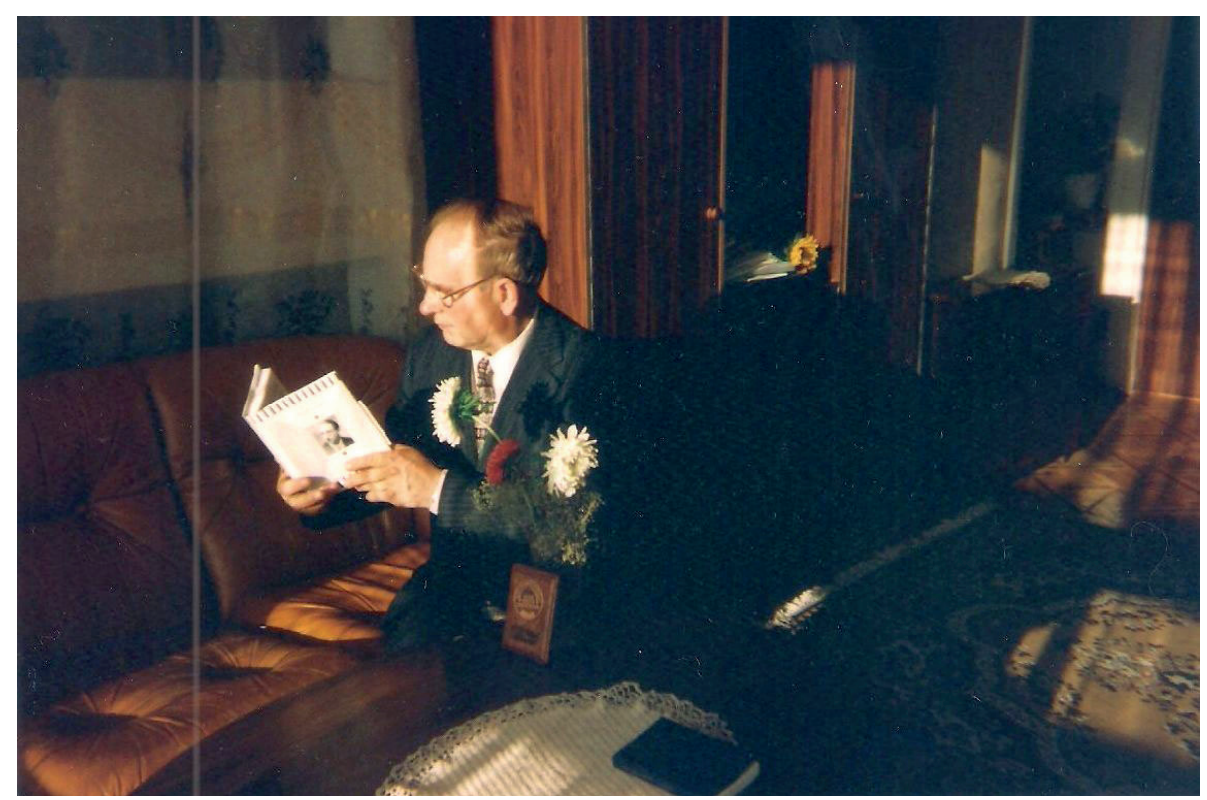

Figure 1. Prof. Ülo Hussar at his home in Arhitekti St., Tartu, 1998.

differentiation in different lymphoid organs - thymus, spleen, lymph nodes. Experimental studies on the development of the thymus were carried out on fish, amphibians, mammals and birds. Ülo Hussar is the author of approximately 200 research papers and over 10 books.

Besides the enthusiastic research work at the Institute of Anatomy (the former Department of Anatomy, Histology and Embryology), Faculty of Medicine of the University of Tartu, Ülo Hussar taught practical classes and delivered lectures on histology and embryology to medical doctors, dentists, pharmacists, sports doctors at different levels of study, at first to Estonian- and Russianlanguage groups and later, after the restoration of the Republic of Estonia, also to English-language groups, preparing himself the teaching materials in three languages. He worked at the Institute of Anatomy, Faculty of Medicine of the University of Tartu, as an assistant from 1963-1969, a senior lecturer from 1969-1974, and in 1974, after the defence of his doctoral thesis, was promoted to become Professor of Histology and Embryology. During the years of his repression from 1977-1982, he was forced to work at the Institute of General and Molecular Pathology, University of Tartu. Returning to the Institute of Anatomy in 1982, he continued, alongside research, teaching students and was also the supervisor of several Candidates of Medicine (Jevgeni Luschikov, Tiiu 


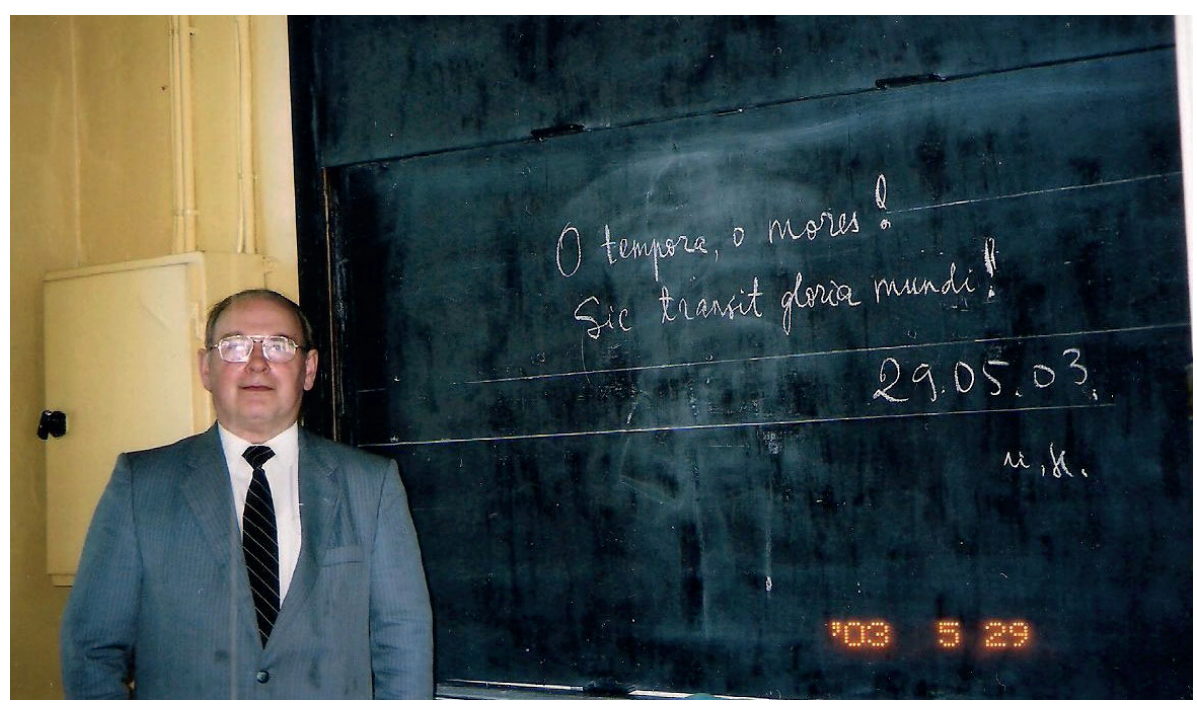

Figure 2. Ülo Hussar visiting his lifelong workplace - the Old Anatomical Theatre as a Professor Emeritus in 2003.

Schattschneider, Jaagup Alaots, Andres Arend) and doctoral students (Oleg Milenin, Piret Hussar - supervised by Ülo Hussar as a Professor Emeritus) who successfully defended their theses.

From 1989-1998 Prof. Ülo Hussar worked as Head of the Institute of Anatomy until the required retirement at the age of 65 according to the rules of the University of Tartu at that time. Ülo Hussar died after a severe illness on 27 November 2008, at the age of 75, in the house built with his own hands supported by his family of wife and three children, in Tartu.

For successful research and long-term teaching, Prof. Ülo Hussar was honoured with the medals of the University of Vilnius (Lithuania), University of Gunma (Japan) and the University of Tartu - Medals of A. Rauber, P. F. Lesgaft and K. E. von Baer.

\section{REFERENCES}

Some textbooks by Prof. Ülo Hussar:

1. Hussar Ü. (1986). Vereloome-ja immuunorganite histoloogia. Tartu: TRÜ Kirjastus.

2. Tehver J., Hussar Ü. (1986). Suuõõne ja hammaste histoloogia. Tartu: TRÜ Kirjastus. 
3. Hussar Ü. (1988). Embrüoloogia põhimõisted. Tartu: TRÜ Kirjastus.

4. Arend Ü., Hussar Ü., Roosaar P. (1988). Tsirkulatsiooniorganite histoloogia. Tartu: TRÜ Kirjastus.

5. Keyserlingk D. von, Hussar Ü. (1992). Neurohistoloogia. Tartu: TÜ Kirjastus.

6. Hussar Ü. (1995). Tsütoloogia: diplomi-, kraadi-ja täiendõppe valikkursus. Tartu: TÜ Kirjastus.

7. Tehver J., Hussar Ü. (1996). Meditsiinihistoloogia seletussõnaraamat: eesti, vene, inglise ja saksa keeles. Tartu: TÜ Kirjastus.

8. Hussar P., Hussar Ü., Kärner J., Suuroja T. (2005). Histoloogia. Miniloengud. Praktikumid. Tartu: OÜ Halo Kirjastus.

9. Tehver J., Hussar P., Hussar Ü., Suuroja T. (2007). Erihistoloogia. Tartu.

Address for correspondence:

Piret Hussar, M.D., D.M.Sc

Chair of Histology and Embryology, Department of Anatomy

Institute of Biomedicine and Translational Medicine, Faculty of Medicine

University of Tartu, Ravila 19, Tartu 50411, Estonia

E-mail: piret.hussar@ut.ee 